\title{
EFFECTS OF SAFFRON (CROCUS SATIVUS L.) CORM PLACEMENT POSITION AND CORM SIZE ON STIGMA AND CORM YIELDS
}

\author{
Neşet Arslan, ${ }^{\mathrm{a}}$ Amir Rahimi, ${ }^{\mathrm{a} *}$ Arif Ipek, ${ }^{\mathrm{b}}$ and Gökhan Ipek, ${ }^{\mathrm{a}}$ \\ a Ankara University, Agriculture Faculty, Field Crops Department, Ankara, Turkey. \\ ${ }^{\mathrm{b}}$ Çankırı University, Science Faculty, Biyology Department, Çankırı, Turkey. \\ *Corresponding author: emir10357@gmail.com
}

\begin{abstract}
Saffron (Crocus sativus L.) is an important medicinal and spice of Turkey. Saffron cultivation has decreased in Turkey has confined to only in three villages in Safran Bolu district of Karabuyuk province. It is triploid and exclusively propagated vegetatively by corms. In Turkey, saffron is traditionallly planted by placing corms in rows randomly without grading or sorting; which results in placement of corms in vertical, horizontal and reverse positions in rows randomly. The study aimed to find the effect of corm size and position of placement in rows on saffron's stigma and corms yield. This study was carried out at the experimental fields of the Department of Field Crops, Faculty of Agriculture, Ankara Univeristy, during 2010-2011 using four different corms size and three placement positions in three replications. The results showed that position of corms and their size had significant effect on stigma yield. Whereas, corm yield was influenced by corm size only.
\end{abstract}

Keywords: Cultivation; Grading; Triploid; Vegetative.

\section{Introduction}

Saffron (Crocus sativus L.) is known as one of the earliest cultivated plants [1]. This plant is an important crop cultivated for its spice for at least 3,500 years. Saffron is a perennial spice and is widely distributed in the Mediterranean region and west of Asia from 10 west to 80 east degrees of geographical longitude, as well as from 30 to 50 north degrees of geographical latitude and altitude of $1000 \mathrm{~m} \mathrm{[2].}$ Currently, it is cultivated more or less intensively in Iran, Kashmir (India), Greece, Spain, Italy, Turkey, France, Switzerland, Israel, Pakistan, Azerbaijan, China, Egypt, United Arab Emirates, Japan, Afghanistan, Iraq and recently Australia (Tasmania) [3]. In the Mediterranean region, saffron is cultivated on a much smaller scale in Italy, Greece and Turkey. In Turkey, it is currently grown in three villages namely - Davutobasi, Yoruk and Asagiguney in the Safranbolu district of Karabuk province [4]. Until the first quarter of 20th century, Safranbolu region was a growing and trading center for saffron, and the region is named after saffron itself (Safran=Saffron, pol or bol $=$ city) [5].

Saffron is classified into Magnoliophyta division, class Liliopsida and order Asparagales. It is a member of Iridaceae family and Crocus L. genus. Iridaceae family includes about 60 genera and 1,500 species. The plants belonging to this family are herbs with rhizomes, corms or bulbs. The Crocus genus includes approximately 80 species spread worlwide [6] of which 32 are included in the Flora of Turkey and 18 of them are endemic to Turkey [7]. The major components of saffron are crocins, picrocrocin and safranal. Crocins is responsible for the colour of saffron, whereas picrocrocin and safranal are responsible for its bitter taste and aroma [8].
This plant is applicable in food, cosmetic and dying industries and pharmaceutical uses. This plant has some advantages such as less water requirement, optimal growing season according to the farmer's views and great opportunities for job and exchange remunerative. Recently, it has been found useful against cancer treatments [9].

This plant is a sterile autumn-flowering species [10] and propagates by vegetative reproduction through the formation of daughter corms from the mother corm [11]. An important factor in saffron-stigma production is the planting of large corms [7]. Corms placement positions (vertical, horizontal and reverse) is another probable factor in saffron-stigma production. In recent years, some studies have been made in order to progress saffron cultivation in Turkey. In these studies, the biggest handicap is the lack of corm material.

This study aims to evaluate the effects of corms size and placement positions on saffron's stigma and reproductive daughter corm yield (propagation) under the field conditions.

\section{Materials and Methods}

The trial was carried out at the experimental fields of the Department of Field Crops, Faculty of Agriculture, Ankara Univeristy, during 2010-2011. The long term outdoor meteorological data and soil analysis results of the of the experimental area are shown in. Table- 1 and 2 respectively. Saffron corms were obtained from the Directorate of Agriculture, Karabük Province. Corms were classified according to the corm as $6 \mathrm{~cm}, 7 \mathrm{~cm}, 8 \mathrm{~cm}$ and $9 \mathrm{~cm}$ (Table-3).

Corm planting was done on 30th September 2010 using split-plot design with three replications. Planting was performed as $20 \times 10 \mathrm{~cm}$ of plant 
spacing with corm sizes as main plots and placement positions (vertical, horizontal and reverse) as subplots. Each plot consisted of 3 rows with 60 corms. Each plot was $0.6 \mathrm{~m} \times 2 \mathrm{~m}=1.2 \mathrm{~m}$. No fertilization and irrigation were done. The flower harvesting was done at the during November 2010. Similarly, the corms were harvested on 2 June 2011. Statistical analyses of data were performed by MSTAT-C program. One-way ANOVA was used for the determining differences between groups. When the P-values were significant, Duncan's multiple range test was performe.

\section{Results}

\section{Corm Yield}

Corm yield $(\mathrm{kg} / \mathrm{d})$ relating to different corm size $(\mathrm{cm})$, placement positions and interaction between two factors are shown in Table-4, Table-5 and Table- 6 respectively $(10 \mathrm{~d}=1 \mathrm{ha})$. Corm yield was affected statistically $(\mathrm{p}<0.01)$ by corm size. Corm yield with respect to corm perimeter changed between $545 \mathrm{~kg} / \mathrm{d}(6 \mathrm{~cm})$ and $1377 \mathrm{~kg} / \mathrm{d}(9 \mathrm{~cm})$. There was no significant difference between three placement positions. With respect to this factor, the highest corm yield $(931 \mathrm{~kg} / \mathrm{d})$ was recorded from the horizontal placement while the lowest yield (859.9 $\mathrm{kg} / \mathrm{d}$ ) was obtained from the reverse placement. Interaction between two factors was not significant. With respect to interaction, the highest corm yield (1441 kg/d) was recorded from the combination of vertical placement and $9 \mathrm{~cm}$ of corm size while the lowest yield $(535 \mathrm{~kg} / \mathrm{d})$ was obtained from the combination of horizontal placement and $6 \mathrm{~cm}$ of perimeter.

\section{Stigma Yield}

Stigma yield $(\mathrm{g} / \mathrm{d})$ relating to different corm size $(\mathrm{cm})$, placement positions and interaction between two factors are shown in Table-4, 5 and 6 respectively. Stigma yield was affected statistically $(\mathrm{p}<0.01)$ by corm size and placement position $(\mathrm{p}<0.01)$. Stigma yield with respect to corm perimeter changed between $91.4 \mathrm{~g} / \mathrm{d}(7 \mathrm{~cm})$ and $530.2 \mathrm{~g} / \mathrm{d}(9$ $\mathrm{cm})$. With respect to placement position, the highest yield $(329.3 \mathrm{~g} / \mathrm{d})$ was recorded from the vertical placement while the lowest yield $(213.9 \mathrm{~g} / \mathrm{d})$ was obtained from the reverse placement. Interaction between two factors was not significant. With respect to interaction, the highest stigma yield $(657.22 \mathrm{~g} / \mathrm{d})$ was recorded from the combination of vertical placement and $9 \mathrm{~cm}$ of corm size while the lowest yield $(62.22 \mathrm{~g} / \mathrm{d})$ was obtained from the combination of reverse placement and $7 \mathrm{~cm}$ of perimeter.

\section{Variation of Corm Yield in Size after harvesting}

The variation of corm yield $(\mathrm{kg} / \mathrm{d})$ in size after harvesting in different corm perimeter $(\mathrm{cm})$ and placement position are presented in Table-7. Corm number per $1.2 \mathrm{~m} 2$ and corm weight $(\mathrm{kg} / \mathrm{d})$ increased sharply with increasing of corm perimeter. Larger corms produced more corm number and corm weight $(\mathrm{kg} / \mathrm{d})$ compared to smaller corms. In every corm size, the corm number in reverse placement position was more than other placement position but the corm weight is random. It was interesting to note that smaller corms tended to produce more number of larger corms compared to larger corms which tended to produce more number of smaller corms.

Table-1: The long term outdoors climatic data (average) of the experimental city (1926-2008)

\begin{tabular}{cccc}
\hline Months & Rainfal $(\mathbf{m m})$ & Temperature $\left(\mathbf{C}^{\mathbf{o}}\right)$ & Humidity (\%) \\
\hline September & 6.8 & 20.4 & 46.4 \\
October & 29.0 & 14.9 & 59.1 \\
November & 49.6 & 5.7 & 72.1 \\
December & 33.2 & 0.9 & 78.0 \\
January & 33.1 & 0.7 & 76.5 \\
February & 38.1 & 0.7 & 73.1 \\
March & 24.5 & 6.4 & 63.0 \\
April & 39.8 & 12.6 & 57.8 \\
May & 47.9 & 16.1 & 56.6 \\
June & 20.5 & 20.1 & 50.5 \\
July & 8.8 & 23.5 & 45.9 \\
August & 6.3 & 23.4 & 46.5 \\
\hline
\end{tabular}

Table-2: Soil analyses results of the experimental soil samples in the field before corm sowing

\begin{tabular}{ccc}
\hline Depth & $\mathbf{0 - 2 0}(\mathbf{c m})$ & $\mathbf{2 0}-\mathbf{4 0}(\mathbf{c m})$ \\
\hline $\mathrm{pH}$ & 7.33 & 7.26 \\
$\mathrm{CaCO}_{3} \%$ & 9.00 & 10.0 \\
Organic Material\% & 1.14 & 1.02 \\
Salt \% & 0.063 & 0.076 \\
$\mathrm{Sand} \%$ & 39.99 & 35.31 \\
$\mathrm{Clay} \%$ & 22.18 & 24.35 \\
Loam \% & 37.83 & 40.24 \\
$\mathrm{P}_{2} \mathrm{O}_{5} \mathrm{~kg} / \mathrm{da}$ & 5.3 & 4.5 \\
$\left.\mathrm{~K}_{2} \mathrm{O} \mathrm{kg/da} / \mathrm{d}\right)$ in different corm perimeter $(\mathrm{cm})^{122}$
\end{tabular}

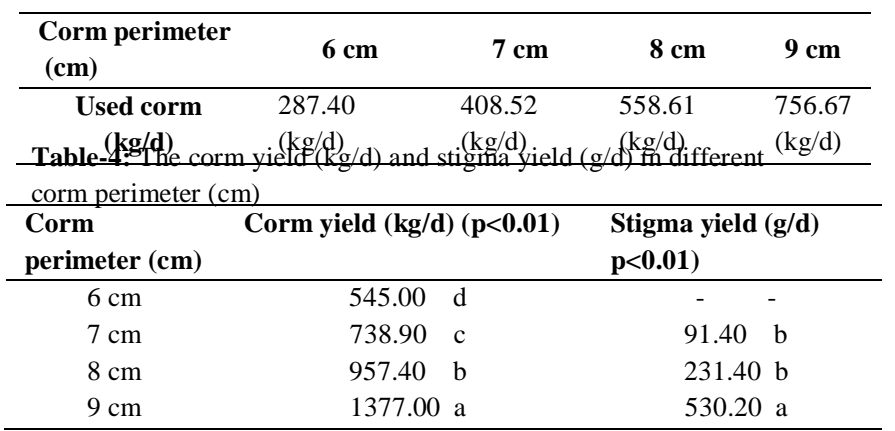


Table-5: The corm yield $(\mathrm{kg} / \mathrm{d})$ and stigma yield $(\mathrm{g} / \mathrm{d})$ in different placement position

\begin{tabular}{lcc}
\hline Placement Positions & Corm yield $(\mathbf{k g} / \mathbf{d})$ & $\begin{array}{c}\text { Stigma yield }(\mathbf{g} / \mathbf{d}) \\
(\mathbf{p}<\mathbf{0 . 0 1})\end{array}$ \\
\hline Vertical & $923.00-$ & $329.30 \quad \mathrm{a}$ \\
Horizontal & $931.00-$ & $309.80 \quad \mathrm{a} \mathrm{b}$ \\
Reverse & $859.90-$ & $213.90 \quad \mathrm{~b}$ \\
\hline
\end{tabular}

Table-6: The corm yield $(\mathrm{kg} / \mathrm{d})$ and stigma yield $(\mathrm{g} / \mathrm{d})$ in different corm perimeter $(\mathrm{cm})$ and placement position (interaction)

\begin{tabular}{|c|c|c|c|c|c|c|c|c|}
\hline \multirow{2}{*}{$\begin{array}{l}\text { Cor } \\
\text { m } \\
\text { size } \\
\text { (cm) }\end{array}$} & \multicolumn{4}{|c|}{ Corm yield $(\mathrm{kg} / \mathrm{d})$} & \multicolumn{4}{|c|}{ Stigma yield $(g / d)$} \\
\hline & $\begin{array}{l}\text { Vert } \\
\text { ical }\end{array}$ & $\begin{array}{l}\text { Horiz } \\
\text { ontal }\end{array}$ & $\begin{array}{l}\text { Rev } \\
\text { erse }\end{array}$ & $\begin{array}{c}\text { Aver } \\
\text { age }\end{array}$ & $\begin{array}{l}\text { Vert } \\
\text { ical }\end{array}$ & $\begin{array}{l}\text { Horiz } \\
\text { ontal }\end{array}$ & $\begin{array}{l}\text { Rev } \\
\text { erse }\end{array}$ & $\begin{array}{c}\text { Aver } \\
\text { age }\end{array}$ \\
\hline 6 & 547 & 535 & 552 & 545 & - & - & - & - \\
\hline 7 & 741 & 772 & 702 & 739 & $\begin{array}{l}87 \\
\end{array}$ & 124 & 62 & 91 \\
\hline 8 & 962 & 988 & 921 & 957 & 243 & 280 & 171 & 231 \\
\hline 9 & 1442 & 1425 & 1263 & 1377 & 657 & 525 & 408 & 530 \\
\hline $\begin{array}{l}\text { Aver } \\
\text { age }\end{array}$ & 923 & 930 & $\begin{array}{l}859 \\
\end{array}$ & - & 329 & 309 & 213 & - \\
\hline
\end{tabular}

\section{Discussion}

The results showed that corm size had significant effect on corm yield. Many reports indicate that there is a positive correlation between corm size and number of regenerated corms in saffron [12-17]. New regenerated corm number increased when corm perimeter increased. But this rate was low in small corms. Mc Gimpsey et al. [14] obtained $10.540 \mathrm{~kg} / \mathrm{d}$ of corm yield five years after planting using $29 \mathrm{~g}$ corms as the seeding material. The effect of placement position on corm yield was not significant but reverses planting produced lowest corm yield.

Vertical planting can produce more corm yield. Also the corm yield is affected by planting density, some agricultural practices etc. In this study, as no fertilization and irrigation was applied, soil hardening resulted in reduced flower harvest as well as stigma yield. The results showed that corm size and placement position had significant effect on stigma yield.

Table-7: The corm yield $(\mathrm{kg} / \mathrm{d})$ and stigma yield $(\mathrm{g} / \mathrm{d})$ in different corm perimeter $(\mathrm{cm})$ and placement position (interaction)

\begin{tabular}{|c|c|c|c|c|c|c|c|}
\hline \multirow{2}{*}{$\begin{array}{l}\text { Corm } \\
\text { perimeter } \\
\text { (cm) }\end{array}$} & \multirow{2}{*}{$\begin{array}{l}\text { Placement } \\
\text { position }\end{array}$} & \multicolumn{2}{|c|}{ Corm yield $(6 \mathrm{~cm}<$ ) } & \multicolumn{2}{|c|}{ Corm yield ( $6 \mathrm{~cm}$ ) } & \multicolumn{2}{|c|}{ Corm yield $(<6 \mathrm{~cm})$} \\
\hline & & Weight $(\mathrm{kg} / \mathrm{d})$ & $\begin{array}{l}\text { Number } \\
\text { per1 } \mathbf{m}^{2}\end{array}$ & Weight (kg/d) & $\begin{array}{l}\text { Number } \\
\text { per1 } \mathbf{m}^{2}\end{array}$ & Weight $(\mathrm{kg} / \mathrm{d})$ & $\begin{array}{l}\text { Number per1 } \\
\mathrm{m}^{2}\end{array}$ \\
\hline \multirow[t]{3}{*}{$6 \mathrm{~cm}$} & Vertical & $338.3(65 \%)$ & $44.7(36 \%)$ & $83.9(16 \%)$ & $18.8(15 \%)$ & $97.8(19 \%)$ & $60.0(49 \%)$ \\
\hline & Horizontal & $343.3(66 \%)$ & $44.2(39 \%)$ & $83.9(16 \%)$ & $19.2(17 \%)$ & $90.0(18 \%)$ & $50.2(44 \%)$ \\
\hline & Reverse & $355.5(67 \%)$ & $43.1(34 \%)$ & $70.5(13 \%)$ & $15.2(12 \%)$ & $104.4(20 \%)$ & $69.4(54 \%)$ \\
\hline \multirow{2}{*}{$\begin{array}{l}\text { Corm } \\
\text { perimeter } \\
(\mathrm{cm})\end{array}$} & \multirow{2}{*}{$\begin{array}{l}\text { Placement } \\
\text { position }\end{array}$} & \multicolumn{2}{|c|}{ Corm yield $(7 \mathrm{~cm}<$ ) } & \multicolumn{2}{|c|}{ Corm yield ( $7 \mathrm{~cm}$ ) } & \multicolumn{2}{|c|}{ Corm yield $(<7 \mathrm{~cm})$} \\
\hline & & Weight (kg/d) & $\begin{array}{l}\text { Number } \\
\text { per1 } \mathbf{m}^{2}\end{array}$ & Weight (kg/d) & $\begin{array}{l}\text { Number } \\
\text { per1 } \mathbf{m}^{2}\end{array}$ & Weight (kg/d) & $\begin{array}{l}\text { Number per1 } \\
\mathbf{m}^{2}\end{array}$ \\
\hline \multirow[t]{3}{*}{$7 \mathrm{~cm}$} & Vertical & $369.9(51 \%)$ & $39.2(23 \%)$ & $132.8(18 \%)$ & $22.7(13 \%)$ & $219.4(31 \%)$ & $110.8(64 \%)$ \\
\hline & Horizontal & $397.2(53 \%)$ & $40.2(25 \%)$ & $148.9(20 \%)$ & $25.0(15 \%)$ & $206.3(27 \%)$ & $97.2(60 \%)$ \\
\hline & Reverse & $305.5(46 \%)$ & $35.2(19 \%)$ & $147.8(22 \%)$ & $25.2(14 \%)$ & $213.9(32 \%)$ & $125.6(67 \%)$ \\
\hline \multirow{2}{*}{$\begin{array}{l}\text { Corm } \\
\text { perimeter } \\
\text { (cm) }\end{array}$} & \multirow{2}{*}{$\begin{array}{l}\text { Placement } \\
\text { position }\end{array}$} & \multicolumn{2}{|c|}{ Corm yield $(8 \mathrm{~cm}<)$} & \multicolumn{2}{|c|}{ Corm yield $(8 \mathrm{~cm}$ ) } & \multicolumn{2}{|c|}{ Corm yield $(<8 \mathrm{~cm})$} \\
\hline & & Weight (kg/d) & $\begin{array}{l}\text { Number } \\
\text { per1 } \mathbf{~ m}^{2}\end{array}$ & Weight (kg/d) & $\begin{array}{l}\text { Number } \\
\text { per1 } \text { m }^{2}\end{array}$ & Weight (kg/d) & $\begin{array}{l}\text { Number per1 } \\
\text { m }^{2}\end{array}$ \\
\hline \multirow[t]{3}{*}{$8 \mathrm{~cm}$} & Vertical & $353.3(37 \%)$ & $30.0(14 \%)$ & $188.9(20 \%)$ & $24.2(11 \%)$ & $407.2(43 \%)$ & $160.0(75 \%)$ \\
\hline & Horizontal & $355.0(36 \%)$ & $29.2(14 \%)$ & $216.4(23 \%)$ & $26.7(12 \%)$ & $400.0(41 \%)$ & $159.2(74 \%)$ \\
\hline & Reverse & $233.9(26 \%)$ & $18.6(8 \%)$ & $218.3(25 \%)$ & $26.4(11 \%)$ & $439.4(49 \%)$ & $191.3(81 \%)$ \\
\hline \multirow{2}{*}{$\begin{array}{l}\text { Corm } \\
\text { perimeter } \\
(\mathrm{cm})\end{array}$} & \multirow{2}{*}{$\begin{array}{l}\text { Placement } \\
\text { position }\end{array}$} & \multicolumn{2}{|c|}{ Corm yield $(9 \mathrm{~cm}<)$} & \multicolumn{2}{|c|}{ Corm yield ( $9 \mathrm{~cm}$ ) } & \multicolumn{2}{|c|}{ Corm yield $(<9 \mathrm{~cm})$} \\
\hline & & Weight (kg/d) & $\begin{array}{l}\text { Number } \\
\text { per1 } \mathbf{m}^{2}\end{array}$ & Weight (kg/d) & $\begin{array}{l}\text { Number } \\
\text { per1 } \mathbf{m}^{2}\end{array}$ & Weight (kg/d) & $\begin{array}{l}\text { Number per1 } \\
\mathbf{m}^{2}\end{array}$ \\
\hline \multirow[t]{3}{*}{$9 \mathrm{~cm}$} & Vertical & $308.9(24 \%)$ & $21.1(7 \%)$ & $255.0(20 \%)$ & $24.2(9 \%)$ & $725.5(56 \%)$ & $232.2(84 \%)$ \\
\hline & Horizontal & $315.0(24 \%)$ & $20.6(8 \%)$ & $380.5(29 \%)$ & $33.9(14 \%)$ & $618.9(47 \%)$ & $191.9(78 \%)$ \\
\hline & Reverse & $352.8(26 \%)$ & $21.4(7 \%)$ & $279.4(20 \%)$ & $24.4(9 \%)$ & $745.5(54 \%)$ & $243.1(84 \%)$ \\
\hline
\end{tabular}


Larger corms and vertical planting produced more stigma yield than smaller corms and reverse planting. Arslan et al., [7] showed that best result was obtained from 9.00-11.00 cm perimeter of corm. Other researchers indicated that an important factor in stigma yield is the planting of large corms $[1,16,18]$. Hosseini et al. [19] found different results about stigma yield in different studies.

\section{Conclusion}

The results of our study indicate that both stigma yield and corm yield were affected by corm size, while only stigma yield was affected by placement position. In Turkey, saffron is traditionally planted by placing corms in rows randomly without classification which results in placement of corms in vertical, horizontal and reverse in rows at random. This study showed that corm classification should be necessary before planting. Larger corms should be used in order in vertical position to get more stigma yield and regenerate new corms. Small corms should be planted in a different place to get size.

\section{Acknowledgements}

All authors are highly thankful to Prof. Dr. Khalid Mahmood Khawar of the Department of Field Crops, Faculty of Agriculture, Ankara University, Turkey for helping in preparation of the manuscript.

\section{Reference}

1. Ipek, A., N. Arslan and E.O. Sarıhan, 2009. Effects of different planting depth and bulb sizes on yield and yield components of saffron (Crocus sativus L.). Ankara Üniversitesi, Ziraat Fakültesi, Tarım Bilimleri Dergisi, 15(1):38-46.

2. Kafi, M., M.H. Rashed, A. Koocheki and A. Mollafilabi, 2002. Saffron: Production Technology and Processing. Center of Excellence for Agronomy (Special Crops). Faculty of Agriculture, Ferdowsi University of Mashhad, Iran.

3. Nehvi, F.A., S.A. Wani, S.A. Dar, M.I. Makhdoomi, B.A. Allie and Z.A. Mir, (2007). New emerging trends on production technology of saffron (Crocus sativus L.). Proc. II. IS on Saffron Bio. And Techno. Eds.;A. Koocheki et. al. Acta Hort. (ISHS) 739:375381.

4. Vurdu, H., 1993. Plants with Bulbs and Forbidden Protection. Fidan, 60: 2-3

5. Gümüşsuyu, İ., 2003. Top of the spices Saffron (Crocus Sativus L.). Safranbolu Society of Service and Culture Publication, Safranbolu, Turkey, P:12.

6. Fernandez, J.A., 2004. Biology, biotechnology and biomedicine of saffron (Crocus sativus L.). Recent Res. Devel. Plant. Sci., 2: 127-159.

7. Arslan, N., B. Gürbüz, A. İpek, S. Özcan, E. Sarıhan, A.M. Daeshian and A.S. Moghadassi, 2007.
The effect of corm size and different harvesting times on saffron (Crocus sativus L.) regeneration. Acta Hort.(ISHS), 739: 113-117.

8. DeJuan, J.A., H.L. Corcoles, R.M. Munoz and M.R. Picornell, 2009. Yield and yield components of saffron (Crocus sativus L.) under different cropping systems. Ind. Crop Prod, 30: 212-219.

9. Abdullayev, F., 2005. Medicinal use of saffron (Crocus sativus L.). Clinical Biochemistry, 38: 8656.

10. Moraga, A.R., J.L. Rambla, O. Ahrazem, A. Granell and L. Gomez, 2009. Metabolite and target transcript analyses during saffron (Crocus sativus L.) stigma development. Phytochemistry, 70: 1009-1016.

11. Basker, D. and M. Negbi, 1983. Uses of saffron (Crocus sativus L.). Economic Botany, 37: 228236.

12. Arslan, N., 1997. Safran (Crocus sativus L.)'da Tohumluk Materyalin Çoğaltılması.Türkiye'de Tarım, 1(2): 3-4.

13. Deo, B., 2003. Growing saffron (Crocus sativus L.)the world smost expensive spice. Crop \& Food Research. Available on Internet at: www.cropcri.nz/home.

14. Gimpsey, Mc., J.A., M.H. Douglas and A.R. Wallace, 1997. Evaluation of Saffron (Crocus sativus L.) production in New Zealand. New Zealand J. Crop and Hort. Sci., 25:159-168.

15. Gümüşsuyu, İ., 2002. Dünyanın En Pahalı Baharatı Safran (Crocus sativus L.). Safranbolu Hizmet Birliği Kültür Yayını, No: 12

16. Vurdu, H., Z. Çaltu and S. Ayan, 2002. Propagation techniques of Saffron plant (Crocus sativus L.). J. For Fac, Gazi Univ. Kastamonu. 2(2): 175-187.

17. Vurdu, H. and K. Güneş, 2004. Safran Kırmız Altın. Gazi Üniversitesi, Kastamonu Orman Fakültesi.

18. Gresta, F., G.M. Lombardo, L. Siracusa and G. Ruberto, 2008. Effect of mother corm dimension and sowing time on stigma yield, daughter corms and qualitative aspects of saffron (Crocus sativus L.) in a Mediterranean environment. J. Sci. Food Agric., 88: 1144-1150.

19. Hosseini, M., B. Sadeghiand and S.A. Aghamiri, 2004. Influence of Foliar Fertilization on Yield of saffron (Crocus sativus L.). Acta Hort, 650:195-200. 